\title{
Sistem Informasi Pengolahan Kas Sekolah Pada MTs Ibnu Hajar Serasan
}

\author{
Dedy Jauhari ${ }^{1}$, Dwi Nurul Huda ${ }^{2}$, Frisca Oktaria ${ }^{3}$ \\ ${ }^{1,2,3}$ STT Indonesia Tanjungpinang \\ Jln. Pompa Air No. 28 Tanjungpinang Kepulauan Riau Indonesia \\ 11dedy@sttindonesia.ac.id \\ 22dwi.nurulhuda@yahoo.com \\ ${ }^{3}$ oktariafriscastti@gmail.com
}

\begin{abstract}
Intisari - Dalam setiap perusahaan, instansi, organisasi atau badan usaha akan memberikan gaji sebagai kompensasi dari kerja seorang karyawan, disamping pemberian gaji pokok pada karyawannya, setiap instansi seringkali memberikan bonus disamping gaji pokok untuk memacu kinerja dan produktifitas kerja karyawannya dikarenakan seorang karyawan yang menerima bonus tersebut harus memenuhi beberapa kriteria tertentu yang berhubungan dengan kedisiplinan, kinerja, dan produktifitas sesuai yang ditentukan oleh masing-masing instansi atau perusahaan. Bagi setiap usaha yang telah menggunakan sistem informasi berbasis komputer dalam kegiatan usahanya maka memerlukan sistem pendukung keputusan untuk menentukan karyawan manakah yang memiliki prioritas untuk mendapatkan bonus berdasarkan dengan kinerja dan produktifitasnya serta dapat menentukkan besarnya bonus yang pantas untuk diterima karyawan tersebut. Sistem pendukung keputusan ini juga dapat berguna untuk memonitor kinerja karyawan dari waktu ke waktu. Sistem ini juga dapat digunakan sebagai acuan dalam penentuan langkah selanjutnya bagi karyawan yang berprestasi maupun tidak. Dalam penelitian ini akan diangkat sebuah kasus yaitu membuat sebuah aplikasi yang dapat diterapkan dalam penentuan bonus karyawan dengan metode weighted prodiuct yang dibuat dalam satu bentuk sistem informasi berbasis website. Penelitian ini dilakukan dengan metode kualitatif dan pengumpulan data yang dapat membantu dalam membangun aplikasi ini. Kemudian dilakukan pula tinjauan keperluan pengguna dalam proses input dan output. Sehingga didapatlah sebuah sistem yang tidak hanya dapat melakukan penyimpanan data dan perhitungan bonus, namun juga dapat mengedit, menghapus data. Aplikasi ini dibuat dengan bahasa pemrograman PHP dan HTML dengan tools berupa aplikasi visual studio code, MSQL sebagai database serta XAMPP sebagai server untuk menjalankan aplikasi ini.
\end{abstract}

Kata kunci-Weighted Product, Aplikasi, Penentuan Bonus Karyawan, Website.

Abstract - In each company, agencies, organization or business entity will give salary as compensation from work an employee, besides the provision of basic salary its employees, every agency often give a bonus besides basic salary to spur performance and productivity work employees because an employee who receive the bonus had to close some certain criteria concerning their discipline, performance, and productivity according to set by each agencies or company. For any effort who had computer-based information system in their business activities so need the support system the decision to determine employees will that has priority to get a bonus based on with the performance and their productivities are and can menentukkan the size of the bonus deserve to the workers. The support system this decision also could be useful to monitor employee performance from time to time.This system can also be used as a reference in the determination of the next step for employees who performed well or not.In this research will be appointed a case of making an application that can be applied in the determination of a employee with the weighted prodiuct made in one form website based information system. The research is conducted by a method of qualitative and collecting data which can help in building this application.Then also conducted a review the needs of users in the process of input and output.So that found a system that not only can do data storage and calculations, bonus but also can edit, erasing the. This application made by a programming language php and html with tools application Visual Studio Code, MySQL as databases and XAMPP as servers to run this.

Keywords - weighted product, application the determination of bonus, employees . website.

\section{Pendahuluan}

\section{A. Latar Belakang}

Penerapan teknologi informasi saat ini telah menyebar hampir di semua bidang tidak terkecuali dalam pengelolaan dana kegiatan sekolah. Pada perkembangan dewasa ini memungkinkan seluruh kegiatan pengelolaan dana kegiatan memanfaatkan teknologi informasi. Kebutuhan akan Teknologi Informasi sangat berhubungan dengan peran dari pengelolaan kas sekolah yang diperlukan untuk membiayai kegiatan sekolah selama 1 (satu) tahun sebagai bagian dari keseluruhan dana anggaraan kegiatan agar satuan pendidikan dapat melakukan kegiatan pendidikan secara teratur dan berkelanjutan sesuai dengan Standar Nasional Pendidikan.

Dari uraian di atas memberikan gambaran bahwa sistem yang ada sekarang ini masih banyak kesulitan mengontrol anggaran operasional setiap periode waktu yang ditentukan, sehingga masih banyak terdapat anggaran dana kegiatan sekolah yang melebihi dari anggaran yang di tetapkan 
sebelumnya di Rencana Kegiatan Anggaran Sekolah (RKAS). Ini akan berdampak terhadap Program Pemerintah dengan tidak terpenuhinya Program 8 Standar Pendidikan Nasional yang terdiri dari Pengembangan Standar isi Pengelolaan Kurikulum, Pengembangan Standar Proses, Pengembangan Standar Kelulusan, Pengembangan Standar Pendidik dan Tenaga Kependidikan, Pengembangan Standar Sarana dan Prasarana, Pengembangan Standar Pengelolaan, Pengembangan Standar Pembiayaan, dan Pengembangan Standar Penilaian. Sehingga sudah seharusnyalah badan lembaga pendidikan khususnya MTs Ibnu Hajar Serasan dapat menjalankan 8 Program Standar Pendidikan Nasional yang mana telah di tetapkan dengan Peraturan Mendiknas nomor 69 Tahun 2009 yang berbunyi standar biaya operasi nonpersonalia adalah standar biaya yang diperlukan untuk membiayai kegiatan operasi nonpersonalia selama 1 (satu) tahun sebagai bagian dari keseluruhan dana pendidikan agar satuan pendidikan dapat melakukan kegiatan pendidikan secara teratur dan berkelanjutan sesuai Standar Nasional Pendidikan.

Dari permasalahan diatas judul yang akan diteliti ialah "Sistem Informasi Pengolahan Kas Sekolah Pada MTs Ibnu Hajar Serasan".

\section{B. Identifikasi Masalah}

Identifikasi masalah adalah suatu tahapan proses merumuskan masalah yang akan diselesaikan. Berdasarkan latar belakang masalah yang telah diuraikan diatas, masalah yang teridentifikasi yaitu :

1. Pengolahan data keuangan yang masih dilakukan secara manual dan tidak terstruktur dengan baik.

2. Pengolahan data laporan keuangan kegiatan sekolah yang membutuhkan waktu yang cukup lama, karena data keuangan yang ada belum tersingkron dengan timeline kegiatan sekolah.

\section{Tujuan Penelitian}

Tujuan penelitian ini merupakan hasil yang hendak dicapai dalam penelitian yang berkontribusi pada ilmu pengetahuan. Tujuan perancangan Sistem Informasi Pengolahan Kas Sekolah Pada MTs Ibnu Hajar Serasan, yakni sebagai berikut:

\section{a. Tujuan Bagi Mahasiswa:}

1. Sebagai Menerapkan hasil kemampuan yang diperoleh dari akademik ke dunia kerja yang nyata.

2. Menambah wawasan dan pengetahuan pada penulis dalam menyusun suatu sistem pendukung keputusan dimasa yang akan datang

b. Tujuan Bagian Pengguna:
1. Mempermudah pekerjaan staf keuangan dalam pengolahan kas dan pemeliharaan data secara lebih teratur.

\section{LANDASAN TEORI}

A. Sistem

Suatu sistem sangatlah dibutuhkan dalam suatu perusahaan atau instansi pemerintahan, karena sistem sangatlah menunjang terhadap kinerja perusahaan atau instansi pemerintah, baik yang berskala kecil maupun besar. Supaya dapat berjalan dengan baik diperlukan kerjasama di antara unsur-unsur yang terkait dalam sistem tersebut.

Ada berbagai pendapat yang mendefinisikan pengertian sistem, seperti di bawah ini :

1. Jogiyanto Hartono

"Suatu sistem dapat didefinisikan sebagai suatu kesatuan yang terdiri dari dua atau lebih komponen atau subsistem yang berinteraksi untuk mencapai suatu tujuan"

2. Tata Sutabri

"Sistem terdiri dari struktur dan proses. Struktur sistem merupakan unsur-unsur yang membentuk sistem tersebut. Sedangkan proses sistem menjelaskan cara kerja setiap unsur sistem tersebut dalam mencapai tujuan sistem"

Syarat-syarat sistem adalah :

1. Sistem harus dibentuk untuk menyeleasikan tujuan.

2. Elemen sistem harus mempunyai rencana yang ditetapkan.

3. Adanya hubungan diantara elemen sistem

4. Unsur dasar dari proses (arus informasi, energy dan material) lebih penting dari pada elemen sistem.

5. Tujuan organisasi lebih penting dari tujuan elemen klasifikasi sistem.

B. Karakteristik Sistem

Selain itu sebuah sistem juga memiliki karakteristik atau sifat-sifat tertentu, yang merincikan bahwa hal tersebut bisa dikatakan sebagai suatu sistem. berikut: Adapun karakteristik yang dimaksud adalah sebagai

1. Komponen Sistem (Components): Suatu sistem terdiri dari sejumlah komponen yang saling berinteraksi, yaitu saling bekerjasama membentuk satu kesatuan. Setiap subsistem memiliki sifat-sifat dari sistem untuk menjalankan suatu fungsi tertentu dan mempengaruhi suatu proses sistem secara keseluruhan.

2. Batasan Sistem (Boundary): Merupakan daerah yang membatasi antara sistem dengan sistem yang lain atau sistem dengan lingkungan luarnya. Batasan sistem ini memungkinkan suatu sistem dipandang sebagai satu kesatuan yang tidak dapat dipisah-pisahkan.

3. Lingkungan Luar Sistem (Environtment):Lingkungan luar sistem bersifat menguntungkan dan dapat bersifat merugikan sistem tersebut. Lingkungan luar yang menguntungkan merupakan energi bagi sistem tersebut. Dengan demikian, lingkungan luar tersebut harus tetap dijaga dan dipelihara. Lingkungan luar yang merugikan 
harus dikendalikan. Kalau tidak, maka akan mengganggu kelangsungan hidup sistem terebut.

4. Penghubung Sistem (Interface) : Penghubung Sistem merupakan media penghubung antara satu subsistem dengan subsistem lainnya. Melalui penghubung ini memungkinkan sumber - sumber daya mengalir dari satu subsistem akan menjadi masukan (input) untuk subsistem lainnya dengan melalui penghubung.

5. Masukan Sistem (Input) :Masukan Sistem adalah energi yang dimasukkan kedalam sistem. Masukan dapat berupa masukan perawatan (maintenance input) yaitu energi yang dimasukkan supaya sistem tersebut dapat beroperasi, dan masukan sinyal (signal input) yaitu energi yang diproses untuk didapatkan keluaran atau informasi.

6. Keluaran Sistem (Output): Keluaran Sistem adalah hasil dari energi yang diolah dan diklasifikasikan menjadi keluaran yang berguna dan sisa pembuangan. Keluaran dapat berupa masukan untuk subsistem yang lain.

7. Pengolah Sistem (Process): Suatu sistem dapat mempunyai suatu bagian pengolah yang akan merubah masukan menjadi keluaran. Contoh, sistem akuntansi. Sistem ini akan mengolah data transaksi menjadi laporan-laporan yang dibutuhkan oleh pihak manajemen.

8. Sasaran Sistem (Objective): Suatu sistem memiliki tujuan dan sasaran yang pasti. Jika suatu sistem tidak memiliki sasaran, maka operasi sistem tidak ada gunanya. Suatu sistem dikatakan berhasil bila mengenai sasaran atau tujuan yang telah direncanakan.

\section{Klasifikasi Sistem}

Sistem merupakan suatu bentuk integrasi antara satu komponen dengan komponen lain karena sistem memiliki sasaran yang berbeda untuk setiap kasus yang terjadi dalam sistem tersebut. Oleh karena itu, sistem dapat diklasifikasikan dari beberapa sudut pandang diantaranya :

1. Sistem Abstrak (Abstract System) dan Sistem Fisik (Physical System)

Sistem abstrak merupakan sistem yang berupa pemikiran atau ide-ide yang tidak tampak secara fisik. Misalnya sistem teologi, yaitu sistem yang berupa pemikiran-pemikiran hubungan antara manusia dengan Tuhan. Sistem fisik merupakan sistem yang ada secara fisik. Misalnya sistem komputer, sistemakuntansi, dan sistem persediaan barang.

2. Sistem Alamiah (Natural System) dan Sistem Buatan Manusia (Human Made System)

Sistem alamiah adalah sistem yang terjadi melalui proses alam, tidak dibuat manusia. Misalnya sistem perputaran bumi. Sistem buatan manusia adalah sistem yang melibatkan interaksi manusia dengan mesin yang disebut human machine system. Misalnya sistem informasi berbasis komputer.

3. Sistem Tertentu (Deterministic System) dan Sistem Tak Tentu (Probabilistic System)

Sistem tertentu adalah sistem yang beroperasi dengan tingkah laku yang dapat diprediksi. Sebagai contoh adalah hasil pertandingan sepak bola. Sistem tak tentu adalah sistem yang kondisi masa depannya tidak dapat diprediksi karena mengandung unsur probabilitas. Misalnya kematian seseorang.

4. Sistem Tertutup (Closed System) dan Sistem Terbuka (Open System)

Sistem tertutup adalah sistem yang tidak berhubungan dan tidak terpengaruh dengan lingkungan luarnya. Sistem ini bekerja secara otomatis tanpa adanya campur tangan dari pihak di luarnya. Secara teoritis sistem tertutup ini ada, tetapi pada kenyataannya tidak ada sistem yang benar-benar tertutup. Contohnya adalah sistem adat masyarakat Baduy. Sedangkan sistem terbuka adalah sistem yang berhubungan dan terpengaruh dengan lingkungan luarnya. Sistem ini menerima masukan dan menghasilkan keluaran untuk lingkungan luar atau subsistem yang lainnya. Misalnya sistem musyawarah.

D. Informasi

Didalam pengolahan sistem pada akhirnya menghasilkan informasi, untuk itu pendefinisian informasi diperlukan untuk menunjang berhasilnya pengembang sistem yang akan dirancang. Definisi informasi menurut para ahli yaitu :

1. Jogiyanto Hartono "Informasi didefinisikan sebagai hasil dari pengolahan data dalam suatu bentuk yang lebih berguna dan lebih berarti bagi penerimanya yang menggambarkan suatu kejadian-kejadian (event) yang nyata (fact) yang digunakan untuk pengambilan keputusan",

2. Tata Sutabri "Informasi adalah sebuah istilah yang tidak tepat dalam pemakaiannya secara umum. Informasi dapat mengenai data mentah, data tersusun, kapasitas sebuah saluran komunikasi, dan lain sebagainya"

Informasi dalam suatu lingkungan sistem informasi memiliki beberapa ciri-ciri yaitu :

1. Benar atau salah, Ini dapat berhubungan dengan realitas atau tidak bila penerimaan informasi yang salah dipercayai mengakibatkan sama seperti benar.

2. Baru, informasi dapat sama sekali baru dan segar bagi penerimanya.

3. Tambahan, informasi dapat memperbaharui atau memberikan tambahan baru pada informasi yang telah ada.

4. Korektif, informasi dapat menjadi suatu korektif atas informasi yang salah.

5. Penegas, informasi dapat mempertegas informasi yang telah ada, ini berguna karena meningkatkan persepsi penerimanya atau kebenaran informasi tersebut.

Kualitas dari suatu informasi tergantung dari tiga hal yaitu informasi harus akurat, tepat pada waktunya dan relevan.

1. Akurat

Informasi harus bebas dari kesalahan-kesalahan. Akurat juga berarti informasi harus jelas mencerminkan maksudnya. Informasi harus akurat karena dari sumber informasi sampai penerima informasi kemungkinan banyak terjadi gangguan yang dapat mengubah atau merusak informasi tersebut.

2. Tepat pada waktunya 
Informasi yang dating pada si penerima tifak boleh terlambat. Informasi yang sudah using tidak akan memiliki nilai lagi karena informasi merupakan landasan dalam pengambilan keputusan.

3. Relevan

Informasi tersebut mempunyai manfaat untuk pemakainya. Relevansi informasi untuk satu orang dengan yang lain berbeda.

Metode pengumpulan informasi yaitu pengamatan langsung, wawancara, perkiraan koresponden dan daftar pertanyaan. Kualitas informasi tergantung dari 3 hal, yaitu informasi harus :

1. Akurat, berarti informasi harus bebas dari kesalahankesalahan dan tidak bisa atau menyesatkan. Akurat juga berarti informasi harus jelas mencerminkan maksudnya.

2. Tepat pada waktunya, berarti informasi yang datang pada penerima tidak boleh terlimbat.

3. Relevan, berarti informasi tersebut mempunyai manfaat untuk pemakainya. Relevasi informasi untuk tiap-tiap orang satu dengan yang lainnya berbeda.

\section{E. Siklus Informasi}

Data yang diolah melalui suatu model menjadi informasi, penerima informasi kemudian menerima informasi tersebut, membuat suatu keputusan dan melakukan tindakan, sehingga menghasilkan suatu tindakan yang lain membuat sejumlah data kembali. Data tersebut diinput, diproses kembali lewat suatu model dan seterusnya hingga membentuk suatu siklus. Siklus ini oleh John Burch disebut dengan nama siklus informasi (information cycle).

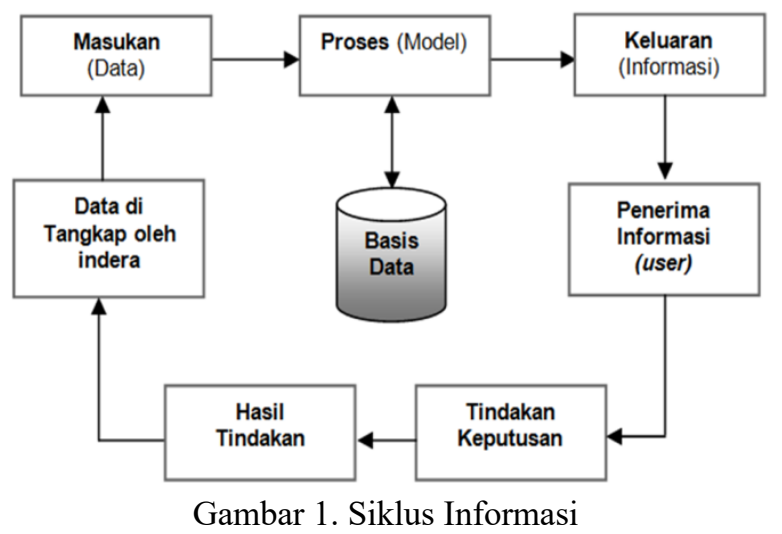

F. Nilai dan Kualitas Informasi

Nilai informasi ditentukan oleh 2 hal, yaitu manfaat dan biaya untuk mendapatkannya. Suatu informasi dikatakan bernilai bila manfaat lebih efektif dibandingkan dengan biaya mendapatkannya. Akan tetapi perlu diperhatikan bahwa informasi yang digunakan didalam suatu sistem informasi umumnya digunakan untuk beberapa kegunaan sehingga tidak memungkinkan dan sulit untuk menghubungkan suatu bagian informasi pada suatu masalah tertentu dengan biaya untuk memperolehnya karena sebagian informasi dinikmati tidak hanya oleh satu pihak didalam perusahaan.

Nilai informasi didasarkan atas 10 sifat :

1. Mudah diperoleh: Sifat ini menunjukkan mudahnya dan cepatnya informasi dapat diperoleh. Kecepatan memperoleh dapat diukur, misalnya 1 menit versus 24 jam. Akan tetapi, berapa nilainya bagi pemakai informasi sulit mengukurnya.

2. Luas dan lengkap: Sifat ini menunjukkan lengkapnya isi informasi. Hal ini tidak berarti hanya mengenai volumenya, tetapi juga mengenai keluaran informasinya. Sifat ini sangat kabur dank arena itu sulit mengukurnya.

3. Ketelitian: Sifat ini berhubungan dengan tingkat kebebasan dari kesalahan keluaran informasi. Dalam hubungannya dengan volume data yang besar biasanya terjadi dua jenis kesalahan, yakni kesalahan pencatatan dan kesalahan perhitungan.

4. Kecocokan: Sifat ini menunjukkan betapa baik keluaran informasi dalam hubungannya dengan permintaan para pemakai. Isi informasi harus ada hubungannya dengan masalah yang sedang dihadapi. Semua keluaran lainnya tidak berguna, tetapi mahal mempersiapkannya. Sifat ini sulit mengukurnya.

5. Ketepatan waktu: Sifat ini berhubungan dengan waktu yang dilalui yang lebih pendek dari pada siklus untuk mendapatkan informasi. Masukan, pengolahan, dan pelaporan keluaran kepada para pemakain biasanya tepat waktu.

6. Kejelasan: Sifat ini menunjukkan tingkat keluaran informasi yang bebas dari istilah-istilah yang tidak jelas. Membetulkan laporan dapat memakan biaya yang besar. Berapa biaya yang diperlukan untuk memperbaiki laporan tersebut?

7. Keluwesan: Sifat ini berhubungan dengan dapat disesuaikannya keluaran informasi tidak hanya dengan lebih dari satu keputusan, tetapi juga dengan lebih seorang pengambil keputusan. Sifat ini sulit diukut, tetapi dalam banyak hal dapat diberikan nilai yang dapat diukut.

8. Dapat dibuktikan: Sifat ini menunjukkan kemampuan beberapa pemakai informasi untuk menguji keluaran informasi dan sampai pada kesimpulan yang sama.

9. Tidak ada prasangka: Sifat ini berhubungan dengan tidak adanya keinginan untuk dipertimbangkan sebelumnya.

10. Dapat diukur: Sifat ini menunjukkan hakekat informasi yang dihasilkan dari sistem informasi formal. Meskipun kabar angina, desas-desus, dugaan-fugaan, klenik dan sebagainya sering dianggap informasi, hal-hal tersebut berapa di luar lingkup pembicaraan kita.

\section{G. Sistem Informasi}

Sistem informasi merupakan suatu sistem didalam suatu organisasi yang merupakan kombinasi dari orang-orang, fasilitas, teknologi, media, prosedur-prosedur dan pengendalian yang ditujukan untuk mendapatkan jalur komunikasi penting, memproses tipe transaksi rutin tertentu, memberi sinyal kepada manajemen dan yang lainnya terhadap kejadian-kejadian internal dan eksternal yang penting dan menyediakan suatu dasar informasi untuk pengambilan keputusan yang cerdik.

1. Komponen dan Jenis Sistem Informasi 
Sistem informasi terdiri dari komponen-komponen yang disebut blok bangunan (building block), yang terdiri dari:

a. Blok Masukan (Input Block) Input mewakili data yang masuk ke dalam sistem informasi. Input di sini termasuk metode dan media untuk menangkap data yang akan dimasukkan, yang data berupa dokumen-dokumen dasar.

b. Blok Model (Model Block) Blok ini terdiri dari kombinasi prosedur, logika dan model mematik yang akan memanipulasi data input dan data yang tersimpan di basis data dengan cara yang sudah tertentu untuk menghasilkan keluaran yang diinginkan.

c. Blok Keluaran (Output Block) Produk dari sistem informasi ini adalah keluaran yang merupakan informasi yang berkualitas dan dokumentasi yang berguna untuk semua tingkatan manajemen serta pemakain sistem.

d. Blok Teknologi (Technology Block) Teknologi merupakan "tool box" dalam sistem informasi. Teknologi digunakan untuk menerima input, menjalankan model, menyimpan dan mengakses data, menghasilkan dan mengirimkan keluaran, dan membantu pengendalian dari sistem secara keseluruhan.

e. Blok Basis Data (Database Block) Basis data (database) merupakan kumpulan data yang saling berkaitan dengan dan berhubungan satu dengan yang lain, tersimpan di perangkat keras komputer dan menggunakan perangkat lunak untuk memanipulasinya.

f. Blok Kendali (Control Block) Banyak hal yang dapat merusak sistem informasi, seperti bencana alam, api, temperature, air, debu, kecurangankecurangan, kegagalan-kegagalan sistem itu sendiri, ketidak efisienan, sabotase, dan lain sebagainya. Beberapa pengendalian perlu dirancang dan diterapkan untuk meyakinkan bahwa hal-hal yang dapat merusak sistem dapat dicegah ataupun bila terlanjur terjadi kesalahankesalahan dapat langsung cepat diatasi.

\section{Metodologi PenElitian}

Metode penelitian rupakan suatu teknik atau cara untuk mengumpulkan data atau fakta yang nantinya akan dipelajari dan akhirnya sebagai bahan untuk di analisa serta digunakan untuk memudahkan pencarian dan pemecahan suatu masalah. Metode penelitian yang digunakan terbagi menjadi 2 yaitu metode pengumpulan data dan metode pengembangan perangkat lunak yang dapat dilihat pada sub bab dibawah ini:

\section{A. Metode Pengumpulan Data}

Dalam kegiatan untuk memperoleh data pada penelitian tugas akhir ini, penulis menggunakan teknik pengumpulan data yang digunakan adalah sebagai berikut :
1. Observasi

Melakukan observasi atau peninjauan tempat sebelum pelaksanaan kegiatan pengumpulan data dengan mengadakan pengenalan terhadap objekobjek penelitian, aktivitas kerja dan bahan kajian pada lembaga bimbingan belajar dSsc. Salman Bandung Kota Tanjungpinang.

2. Wawancara

Melakukan wawancara secara langsung dengan pihak-pihak yang terlibat dalam sistem pendaftaran dan akademik dSsc Salman Bandung.

3. Studi Kepustakaan

Melakukan pengumpulan data secara tidak langsung dengan melakukan studi kepustakaan, yaitu dengan mengumpulkan data-data dan teoriteori yang berhubungan dengan penulisan laporan tugas akhir ini.

\section{B. Metode Pengenbangan Perangkat Lunak}

Metode pengembangan perangkat lunak yang digunakan dalam membangun website informasi ini menggunakan model Waterfall yang menyarankan pengembangan perangkat lunak secara sistematik dan berurutan yang dimulai dari tingkatan sistem tertinggi dan berlanjut ke tahap analisa, desain, pengkodean, pengujian dan pemeliharaan. [9]

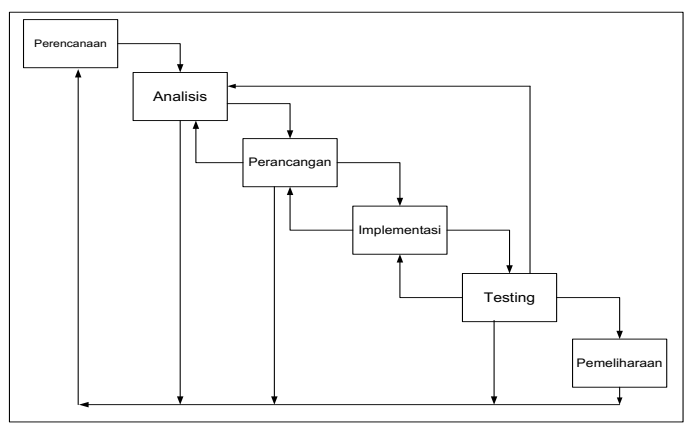

Gambar 1. Model Waterfall [9]

Keterangan :

1. Perencanaan (Engineering System) adalah Tahapan mengenai masalah perangkat lunak, perangkat keras dan sumber daya manusia.

2. Analisis (Analysis) adalah Melakukan analisis sistem dengan mencari penyebab-penyebab masalah yang timbul sabagai dasar perancangan sistem baru.

3. Perancangan (Design) adalah Proses mengubah kebutuhan-kebutuhan menjadi bentuk karakteristik yang dimulai dengan penulisan program design tadi harus diubah menjadi bentuk yang dimengerti sistem.

4. Implementasi (Implementation) adalah Tahap penerjemahan desain kedalam bahasa pemrograman yang sesuai dengan kebutuhan. 
5. Pengkodean (Coding) adalah desain yang harus diubah bentuknya menjadi bentuk yang dimengerti oleh komputer. Tahanpan ini yang secara teknik akan dikerjakan oleh sistem.

6. Pengujian (Testing) adalah Tahap pengujian perangkat lunak yang telah dikembangkan untuk cover kesalahan-kesalahan dan menjamin bahwa mesukan sesuia dengan hasil yang ditentukan.

7. Pemeliharaan (Maintenance) adalah Tahap perawatan sistem yang telah dikembangkan seperti perawatan perangkat lunak, perangkat keras dan media lain yang berhubungan dengan komputer. Pada tahap ini segala kemungkinan mengenai kekurangan perangkat lunak baik berupa kesalahan atau hal-hal yang ditambahkan kedalam perangkat lunak.

\section{IV.HASIL DAN PEMBAHASAN}

\section{A. Perancangan Sistem}

Perancangan sistem yang akan dibangun dan digambarkan secara terstruktur sebelum dilakukan pengkodean kedalam bahasa pemograman. Rancangan Sistem Informasi Pengolahan Kas Sekolah ini di maksudkan untuk menghasilkan suatu sistem informasi baru untuk mendukung operasional Sekolah MTs Ibnu Hajar Serasan. Proses perancangan diperlukan untuk menghasilkan suatu rancangan sistem yang baik, karena dengan adanya rancangan yang tepat maka akan menghasilkan sebuah sistem yang akan memudahkan proses pengembangan sistem dimasa yang akan datang.

B. Perancangaan Prosedur dan Flowmap Usulan

1. Perancangan Prosedur dan Flowmap Pemasukan Kas Sekolah Yang Diusulkan

Merupakan prosedur untuk memanajemen pemasukan keuangan sekolah. Adapun prosedur yang diusulkan adalah sebagai berikut:

a. Kepala sekolah memberikan data jumlah dan asal pemasukan kas sekolah kepada Bagian Keuangan.

b. Bagian keuangan menginput data tersebut ke databaseaplikasi yang dibangun sebagai data pemasukan kas sekolah.

c. Bagian Keuangan membuat laporan data pemasukan kas sekolah sebanyak 2 (dua) rangkap, rangkap pertama diberikan kepada Kepala Sekolah, dan rangkap kedua disimpan sebagai file arsip di Bagian Keuangan yang akan diberikan kepada Kepala sekolah setiap bulan dan setiap akhir tahun. Adapun flowmappemasukan kas sekolah yang diusulkan dapat dilihat sepeti gambar di bawah ini

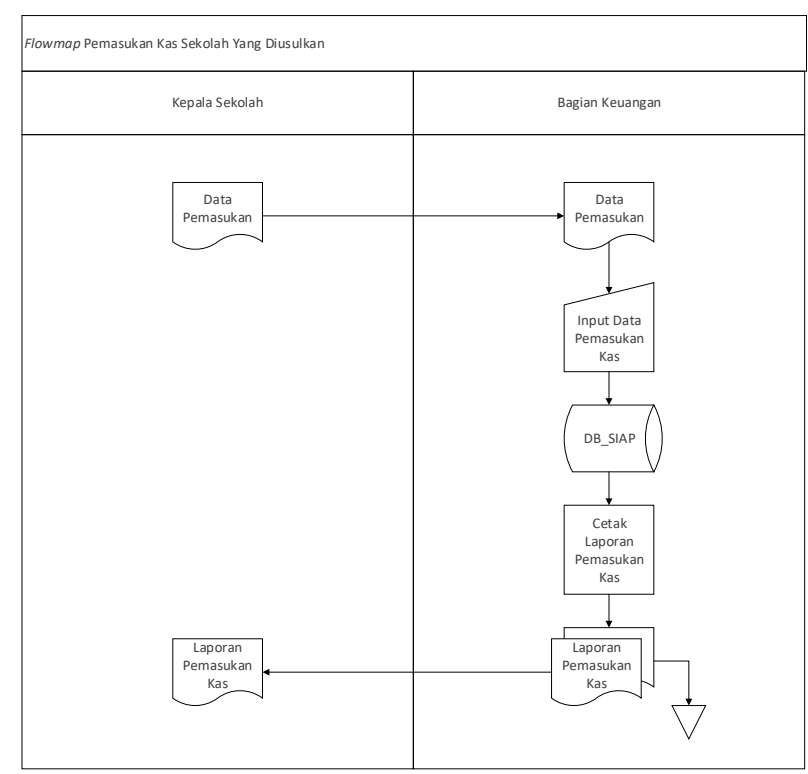

Gambar. Flowmap Pemasukan Kas Sekolah Yang Diusulkan

2. Perancangan Prosedur dan Flowmap Pengeluaran Kas Sekolah Yang Diusulkan

Merupakan prosedur untuk memanajemen pengeluaran kas sekolah. Prosedur ini melibatkan beberapa aktor, yaitu Penanggung Jawab Kegiatan, Kepala Sekolah, dan Bagian Keuangan. Prosedur ini dapat dijelaskan sebagai berikut:

a. Penanggung Jawab Kegiatan sekolah memberikan data kegiatan dan anggaran yang dibutuhkan kepada Kepala Sekolah.

b. Kepada Sekolah memeriksa data kegiatan dan anggaran yang dibutuhkan untuk kegiatan sekolah, jika data tersebut tidak disetujui, maka data tersebut dikembalikan kepada Penanggung Jawab Kegiatan, Tetapi jika data tersebut disetujui oleh Kepala Sekolah, maka data tersebut akan diberikan kepada Bagian Keuangan untuk dicatat.

c. Bagian Keuangan mencatat data kegiatan dan anggaran yang dibutuhkan pada database aplikasi.

d. Bagian Keuangan mencetak laporan pengeluaran dan detail pengeluaran kas berdasarkan data yang tercata pada buku kas sebanyak 2 (dua) rangkap, rangkap pertama diberikan kepada Kepala Sekolah dan rangkap kedua disimpan sebagai file arsip di Bagian Keuangan.

e. Bagian Keuangan juga membuat laporan kas secara keseluruhan yang dicetak sebanyak 2 (dua) rangkap, rangkap pertama diberikan kepada Kepala Sekolah dan rangkap kedua disimpan sebagai file arsip di Bagian Keuangan.

Adapun flowmap pengeluaran kas sekolah yang berjalan dapat dilihat seperti gambar di bawah ini. 


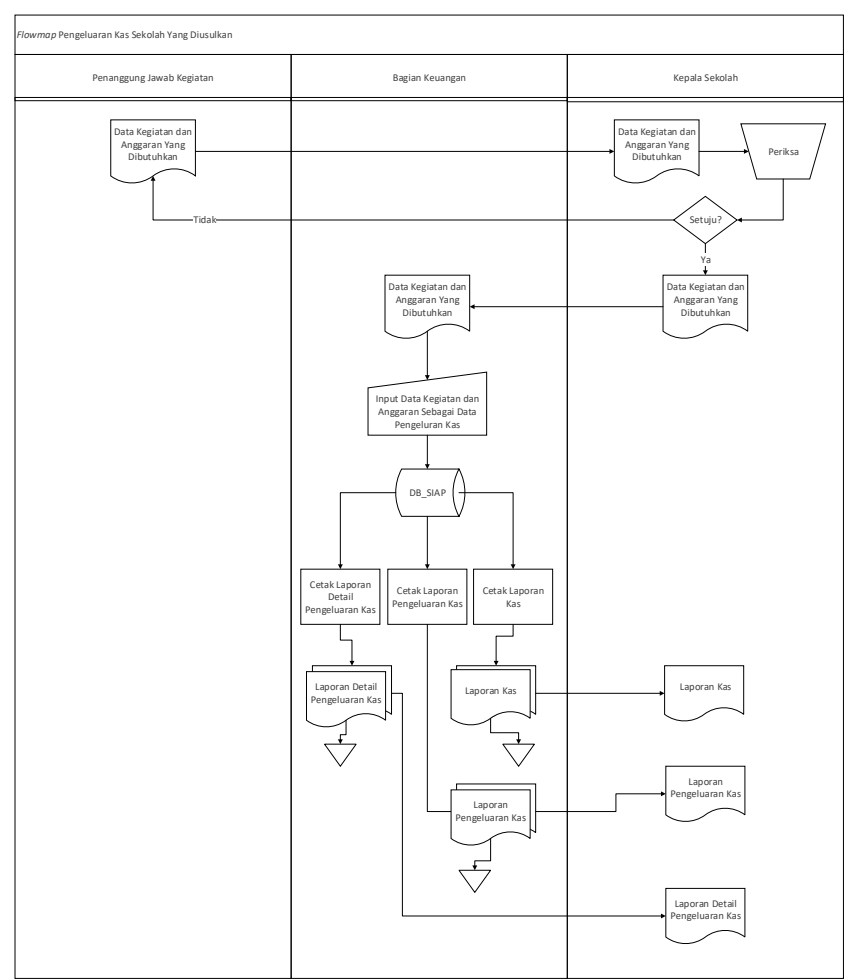

Gambar. Flowmap Pengeluaran Kas Sekolah Yang Diusulkan

C. Perancangan Diagram Konteks

Diagram konteks merupakan alat untuk struktur analisis. Pendekatan terstruktur ini mencoba untuk menggambarkan sistem secara garis besar atau secara keseluruhan. Untuk jelasnya diagram konteks Sistem Informasi Pengolahan Kas Sekolah Pada MTs Ibnu Hajar Serasan dapat digambarkan sebagai berikut:

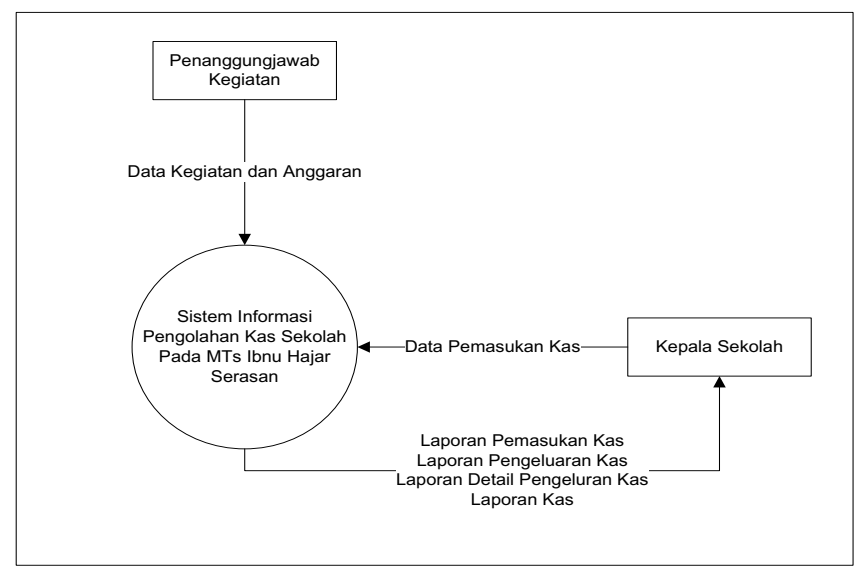

Gambar. Diagram Konteks

D. Implementasi

Implementasi antar muka merupakan tampilan aplikasi yang berfungsi sebagai antar muka masukan data ke dalam database atau output dari database. Tampilan antar muka dapat dilihat pada gambar-gambar sebagai berikut:antar muka masukan data ke dalam database atau output dari database.

1. Implementasi Tampilan Login Form

Merupakan tampilan (interface) yang digunakan untuk melakukan proses login agar dapat mengakses main form dari aplikasi.

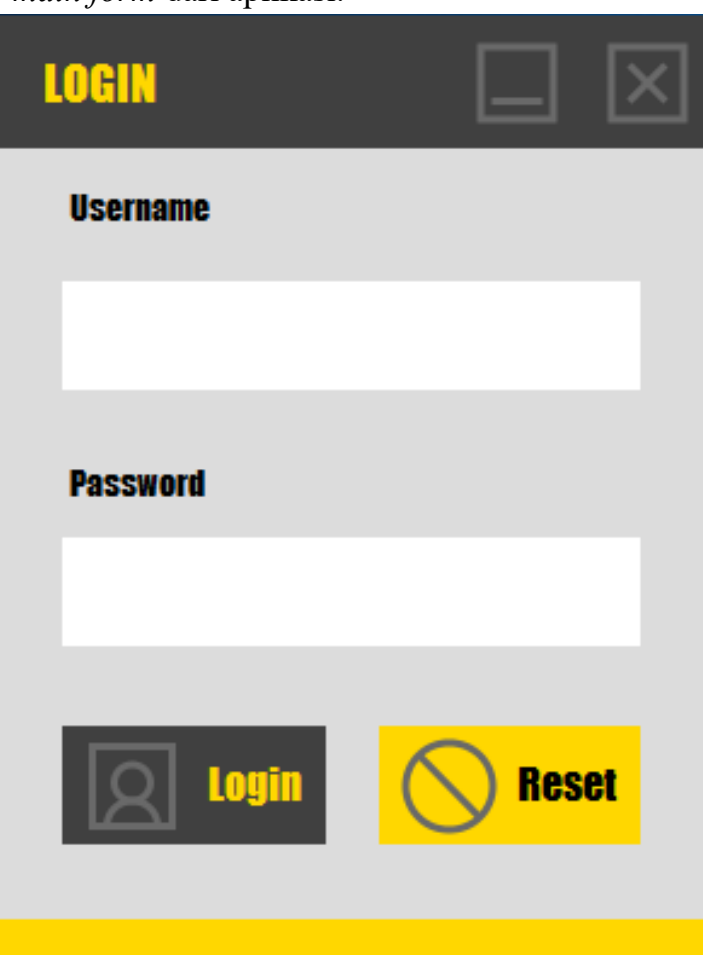

Gambar. Implementasi Tampilan Login Form

2. Implementasi Tampilan Main Form - Menu KAS

Tampilan (interface) yang terdapat informasi mengenai data kas, baik kas masuk, kas Keluar, dan data balancekas.

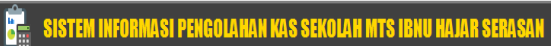

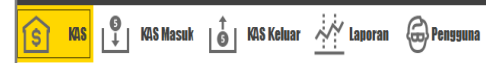

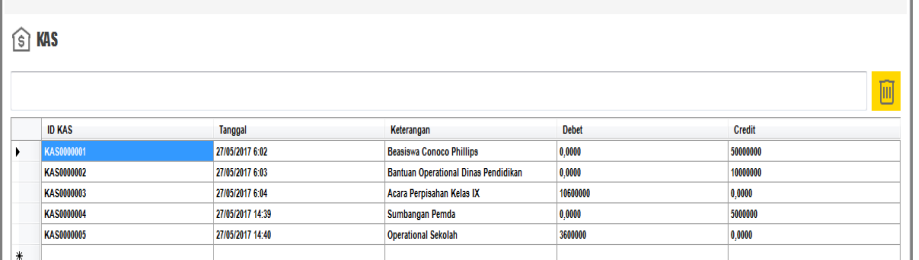

Balance: Rp 50800000

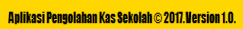

Gambar. Implementasi Tampilan Main Form - Menu KAS 
3. Implementasi Tampilan Main Form - Menu KAS Masuk

Tampilan (interface) yang memuat informasi mengenai data kas masuk. Pada tampilan ini, pengguna dapat langsung menginputkan data kas masuk, dan kemudian dapat melihat hasil inputan pada table kas masuk.

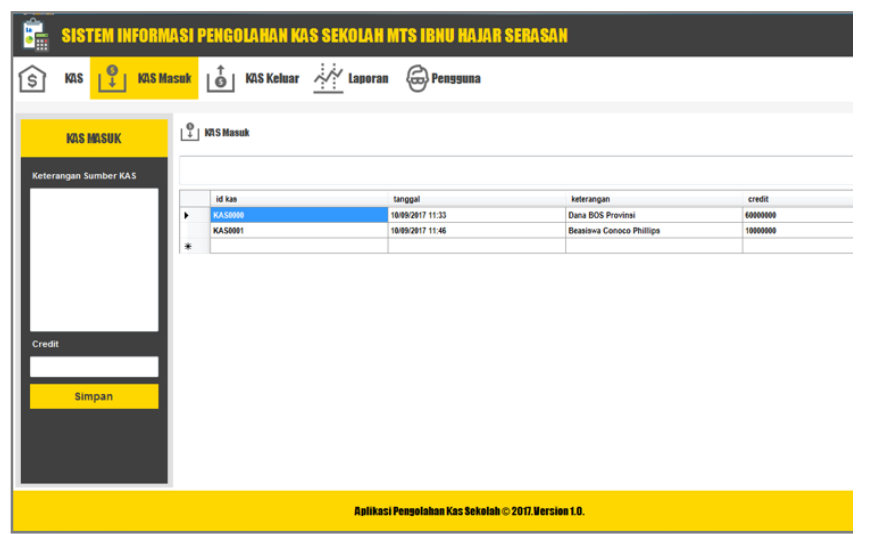

Gambar. Tampilan Main Form - Menu KAS Masuk

4. Implementasi Tampilan Main Form - Menu KAS

Keluar

Tampilan (interface) yang memuat informasi mengenai data kas keluar. Pada tampilan ini, pengguna dapat langsung menginputkan data kas keluar berserta data detailnya, dan kemudian dapat melihat hasil inputan pada table kas keluar.

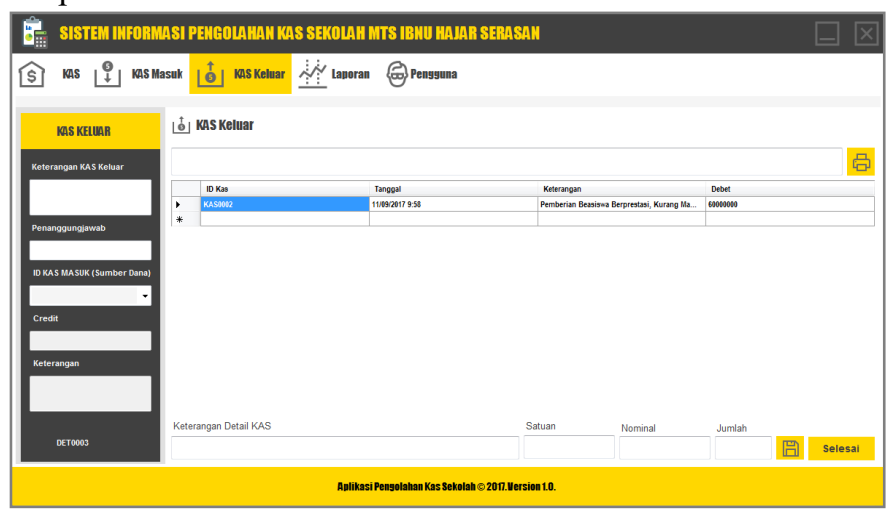

Gambar. Tampilan Main Form - Menu KAS Keluar

Dari tampilan menu KAS Keluar ini, pengguna dapat langsung melihat dan mencetak detail dari kegiatan yang diselenggarakan oleh panitia kegiatan. Laporan detail kegiatan dapat dilhat pada gambar di bawah ini.

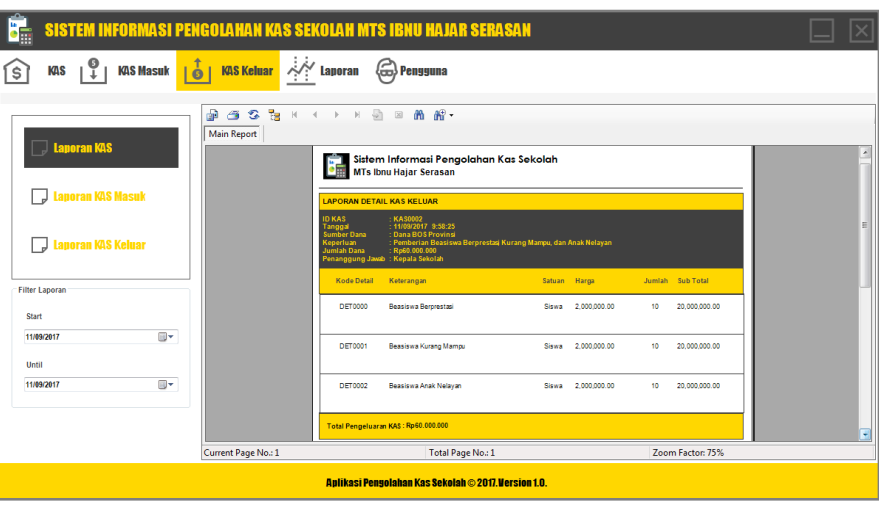

Gambar. TampilanMain Form - Laporan Detail Kegiatan

5. Implementasi Tampilan Main Form - Menu Laporan

Tampilan (interface) yang terdapat report viewer. Pengguna dapat melihat laporan kas, laporan kas masuk, laporan kas keluar secara langsung melalui tampilan ini dengan mengklik button menu laporan disampingnya.

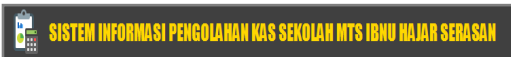

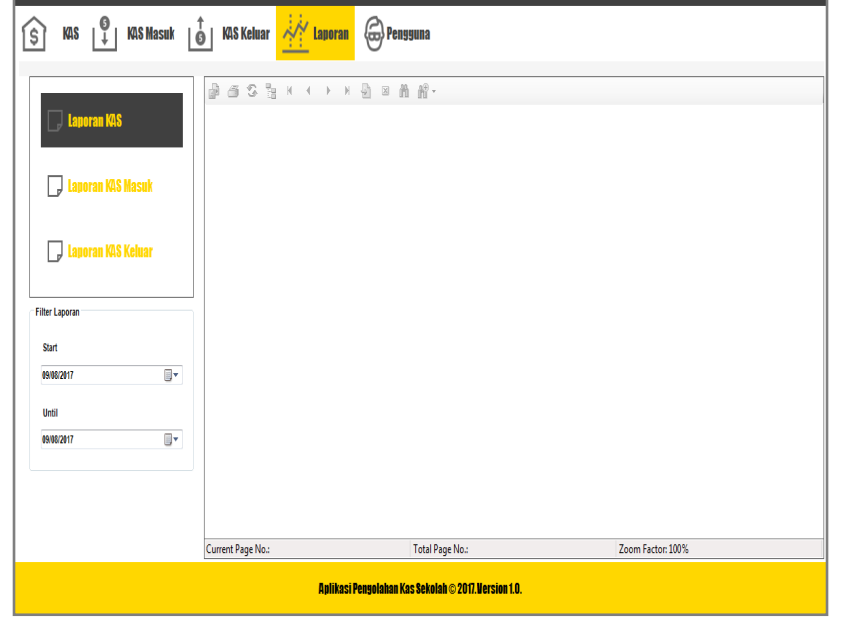

Gambar. TampilanMain Form - Menu Laporan Jika pengguna mengklik button menu Laporan KAS, maka akan tampilan laporan data kas seperti gambar dibawah:

HE

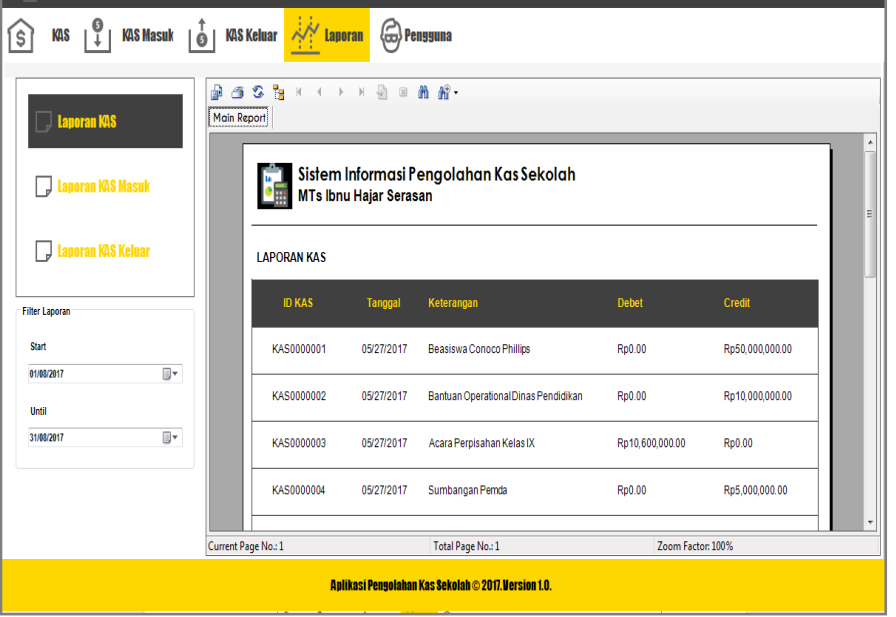


Gambar. TampilanMain Form - Laporan KAS

Jika pengguna mengklik button menu Laporan KAS Masuk, maka akan tampilan laporan data kas masuk seperti gambar ini.

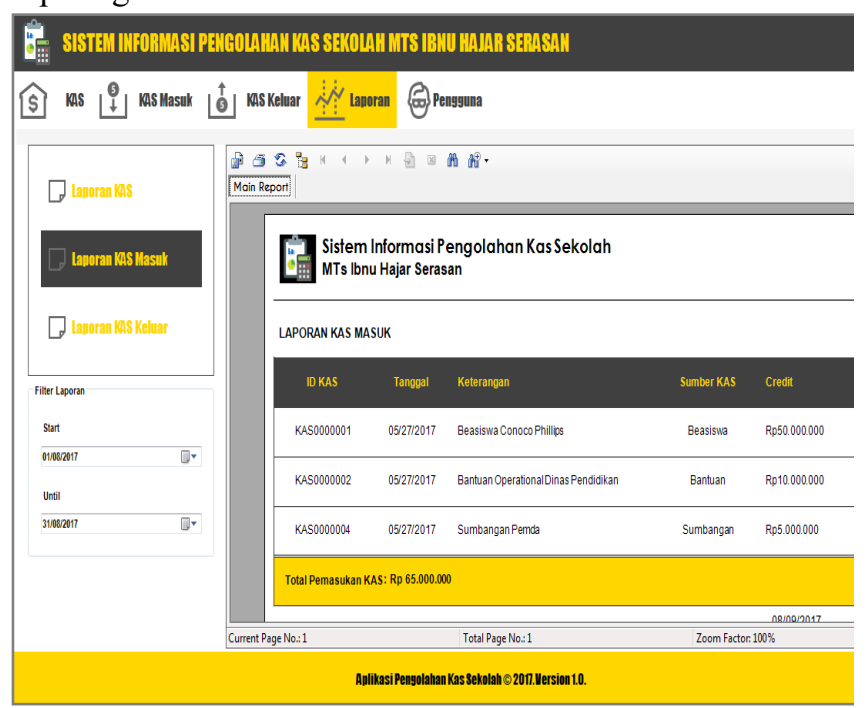

Gambar. TampilanMain Form - Laporan KAS Masuk

Dan jika pengguna mengklik button menu Laporan KAS Keluar, maka akan tampilan laporan data kas keluar seperti gambar di bawah ini.

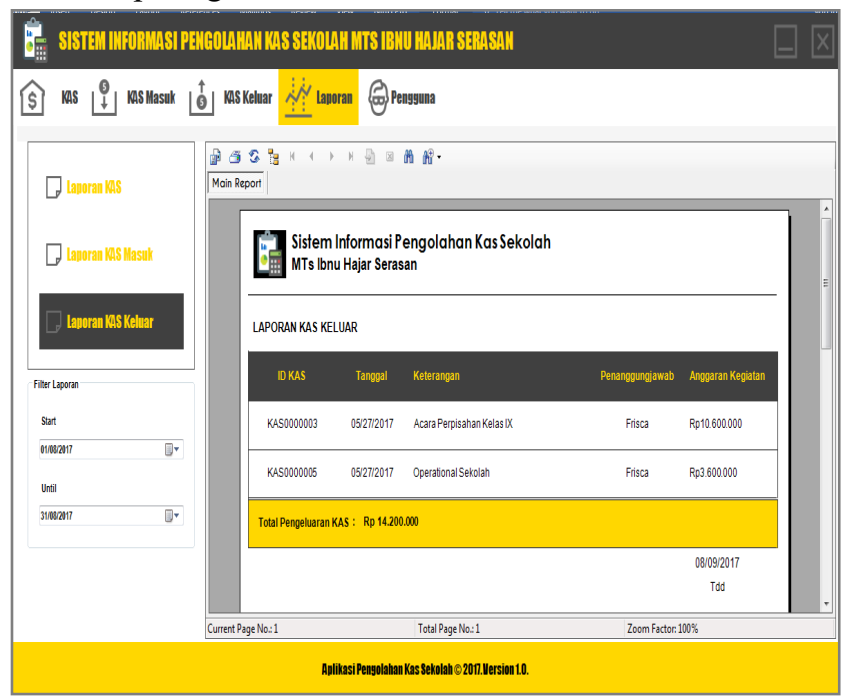

Gambar. TampilanMain Form - Laporan KAS Keluar

6. Implementasi Tampilan Main Form - Menu Pengguna

Tampilan (interface) yang memuat informasi data pengguna dari aplikasi ini.

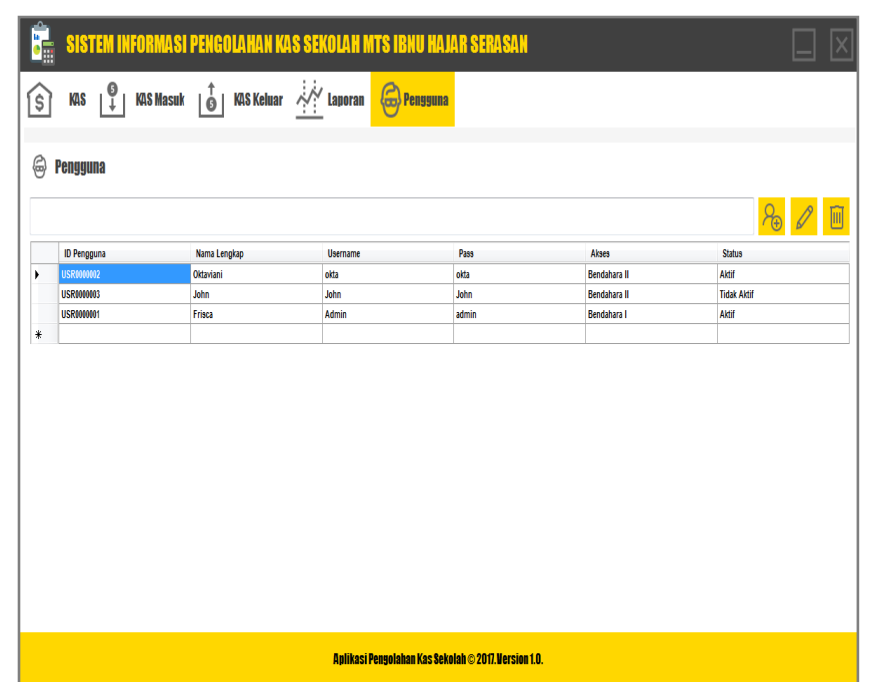

Gambar. TampilanMain Form - Menu Pengguna

Dari tampilan menu pengguna ini, pengguna dapat menambahkan atau mengubah data pengguna dengan memlilih button fungsi yang diinginkan. Jika ingin menambkan data pengguna maka, pengguna harus mengklik button tambah penguna, dan jika ingin mengubah data pengguna, maka pengguna harus mengklik button edit data pengguan. Tampilan (interface) input data pengguna dapat dilhat pada gambar dibawah ini.

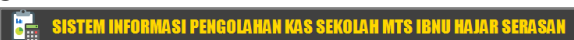

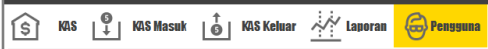

(8) Pengyuna > rambah

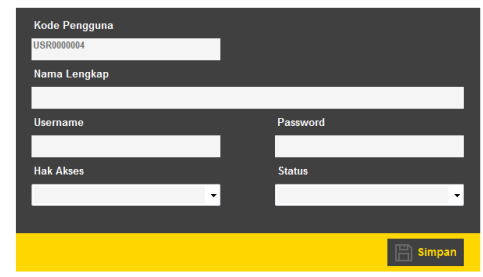

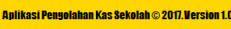

Gambar. TampilanMain Form - Input Data Pengguna

\section{KESIMPULAN}

Berdasarkan hasil pengujian secara keseluruhan dari sistem yang telah dibangun, maka dapat ditarik kesimpulan bahwa perangkat lunak Sistem Informasi Pengolahan Kas Sekolah Pada MTs Ibnu Hajar Serasanbebas dari kesalahan sintaks dan berjalan sesuai dengan yang diharapkan. Adapun tujuan sebelumnya dari penelitian ini dapat terwujud, Dengan Sistem Informasi Pengolahan Kas Sekolah pada MTs Ibnu hajar ini, maka pengolahan data kas sekolah dapat dilakukan secara komputerisasi dan berbasis aplikasi sehingga dapat terstruktur dengan baik. Dengan Sistem Informasi Pengolahan Kas Sekolah pada MTs Ibnu hajar ini, maka pengolahan data laporan kas sekolah menjadi lebih cepat, 
karena data kas yang ada sudah tersingkron dengan timeline kegiatan pengeluaran kas sekolah.

\section{UCAPAN TERIMA KASIH}

Didalam pengerjaan laporan ini, penulis telah melibatkan banyak pihak yang sangat membantu dalam banyak hal. Oleh sebab itu, disini penulis sampaikan rasa terima kasih sedalam-dalamnya kepada :

1. Kepada kedua orang tua tercinta yang selama ini selalu mendoakandan memberikan dorongan moral dan materiil yang tidak ternilai harganya.

2. Dosen Pembimbing Ibu Dwi Nurul Huda, ST, M.Kom atas segala masukan dan sarannya dalam proses penyelesaian pengerjaan laporan ini.

3. Seluruh Dosen dan Staff Sekolah Tinggi Teknologi Indonesia Tanjungpinang yang telah memberikan banyak ilmu dan motivasi selama melaksanakan studi.

4. Rekan-rekan mahasiswa satu angkatan jurusan komputer akuntansi yang selalu bersatu dalam menjalani masa pendidikan di Sekolah Tinggi Teknologi Indonesia Tanjungpinang ini.

5. Semua pihak baik yang berhubungan langsung maupun tidak langsung yang telah mendukung atas terselesaikannya masa studi kami.

Akhir kata penulis mengucapkan terima kasih, semoga Allah SWTmembalas semua kebaikan yang telah diberikan kepada penulis.

\section{REFERENSI}

[1] Elvianna dkk. Buku Panduan Penulisan Laporan Kerja Praktek (KP) dan Skripsi, STTI Tanjungpinang, 2014, Tanjungpinang.

[2] Hanif Al Fatta, analisis \& perancangan sistem informasi, [Andi offset, 2014], Yogyakarta], hal : 9

[3] HM Jogiyanto, Analisis dan Desain Sistem Informasi, Andi, 2005, Yogyakarta..

[4] Nugroho Adi, Analisis dan Perancangan Sistem Informasi dengan Metodologi Berorientasi Objek, Informatika, 2004, Bandung.

[5] Hartono Jogiyanto, Pengenalan Komputer, Andi, 1999, Yogyakarta.

[6] Sutabri Tata, Sistem Informasi Manajemen, Andi, 2005, Yogyakarta.

[7] Rusmawan Uun, Koleksi Program VB.NET untuk Tugas Akhir dan Skripsi, PT Elex Media Komputindo, 2014, Jakarta.

[8] Ngurah Suryantara, Gusti, S.Kom., M.Kom, Merancang Aplikasi Distributor dengan VB.NET, PT Elex Media Komputindo, 2015, Jakarta.

[9] Kadir Abdul, Pengenalan Teknologi Informasi, Andi, 2003, Yogyakarta.

[10] Prof.Dr.Jogiyanto, HM. MBA. Akt, Analisis dan Desain,[Andi.Yogyakarta], hal.8

[11] Prof. Dr. Mr. S. Prajudi Atmosudirdjo, Analisis dan Perancangan Sistem Informasi, Yogyakarta, 2013, hal 9

[12] Roger S. Pressman, Ph.D, Rekayasa Perangkat Lunak, [Yogyakarta, 2007, Andi], hal.364

[13] Nugroho, Adi, 2005, Analisis dan Perancangan Sistem Informasi dengan Metodologi Berorientasi Objek, Informatika Bandung.

[14] Yakub, Pengantar Sistem Informasi, Graha Ilmu, 2014, Yograkarta 